\title{
THE BLACK LIVES MATTER MOVEMENT AND WHY THE RESPONSE OF ALL LIVES MATTER IS MISLEADING
}

\author{
Scott Loken
}

Growing up you would've never expected me to be The type of person to spit these lyrics as an MC But I grew to be someone who cares about all I see I transformed from innocent kid to a man who wants us all free There's no picture that can frame me, I have a complicated mind When I was young I didn't understand all that I've grown to find I knew something was wrong, I could feel it but I was blind Later I used so many books piecing the puzzles of our times There's still so much to learn and I look for the knowledge everyday Too bad the facts we need to know are sometimes hidden and stowed away

The picture gets clearer day by day despite these areas of grey

I got turned on to all this knowledge like it was some good foreplay As a kid it hurt to see the footage from Eyes On The Prize Since before I saw that I just didn't realize All the pain that was forced on people that wouldn't compromise Their dedication gave me strength and now I have open eyes

I use Hip Hop as an outlet, both writing and listening. It's easy to speak out through music and just let your emotions and passions go. Other Hip Hop artists have eloquently expressed how I feel in the past and I use their lyrics at times to speak on the thoughts racing through my mind constantly; as you will see throughout this writing.

\section{INTRODUCTION}

"If you ain't saying nothing, you the system's accomplice It should play with your conscious, do away with the nonsense"

-Black Thought -(Roots 2006)

I have always been inspired by strength in the face of the worst of odds. Historic leaders like Dr. Martin Luther King, Jr., Malcolm X, Medgar Evers, and John Brown fought and died for equality for all citizens (Gray 1995, Hine, Hine and Harrold 2004). Today, in the year 2016, it is about time we all roll up our metaphorical sleeves and get our hands dirty like the great leaders of the past to create the necessary change that our cur- 
rent society so desperately needs for direction and unity. The fact that we still need a true modern day movement for equality is horrible; it is a shame. In fact, it is downright bullshit. As a nation we should have gotten past this long ago.

It seems we are regressing in the modern era as if those in power of our systemically racist government/nation have figured that we would have collective amnesia and not remember what has been done to our fellow citizens.

The sad state of our nation is that people of color, particularly Black males, are viewed as a threat to anyone with whom they come in contact; even if that person is a child of 12 years old (Tamir Rice!) or 17 years old (Trayvon Martin!) (National Urban League 2007). Let us not forget the past examples though. It's nothing new, just ask the family of Emmitt Till, a 14-year-old who fell victim to lynching in 1955 (Blumberg 1991).

This psychologically affects each and every person on every encounter they experience with people who are of a different ethnicity; whether on a large or small scale.

As a 38-year-old white male in our society I am disgusted with our lack of progress. It almost feels like I look through a lens as if I have gone through life for a period of time in a Black man's body like John Howard Griffin (2010) discussed in Black Like Me but I never changed my skin tone and lived life as a Black man myself. When you speak on racial issues in today's society and you do not conform to a specific norm to which you are expected to adhere, you get attacked; based on social norms you are supposed to think a certain way. I feel the responsibility of speaking my experiences to people who need to expand their thinking.

That is why I have to speak out against the response of "all lives matter." Every time I hear that response I cringe. I experience a sense of betrayal that makes it impossible for me to look the other way. That betrayal comes from the discontentment surrounding a response that comes from a perspective held by some whites who feel threatened by anything or anyone who does not adhere to the core beliefs to which they have become accustomed.

Julie Lopez Figueroa (2007) speaks on the affects of how anything outside of what they have been taught "threatens family loyalty and/or they do not want to risk losing social acceptance among peers." However, the misleading part of the "all lives matter" response is the fact that yes, everyone should know that all lives matter but that is not the point. It actually is a correct and true statement, but to really be able to understand the importance of the proclamation that Black Lives Matter, a new perspective has to be considered which is very difficult when the core set 
of values is challenged. This set of norms that was intended to acculturate and assimilate all other cultures was never intended to include Black lives.

I'm going to be up front and honest with you, dear reader. I am the type of person that white racists have always been afraid of; complexionwise I may look like them, but I don't think like them. In Hip Hop there is a term that was created to describe racist America based on the most racist group known in our nation, the Ku Klux Klan. That term is AmeriKKKa. Artists such as Ice Cube, 2Pac, Public Enemy and Spice 1 have used it to describe how they are AmeriKKKa's Nightmare or AmeriKKKa's Most Wanted because they called out many societal ills and were brutally honest.

Well to white racists, I am basically their newest nightmare because of my honesty and how I call out white people for their racism. Omi and Winant spoke about what they described as "racial etiquette," and honestly, I do not conform to a certain racial identity (Racial Formation in the United States 1994). Most whites believe I should "act white" which confuses them; it rocks their foundation and goes against what they were taught is acceptable. In fact, they will go as far as to say that I wish I was Black, or I am ashamed of my race. On the contrary, I'm very proud of who I am as a person, but I do have to say that I am ashamed of the history of the white race and the hate and racism that has been exhibited towards people of color since the birth of the nation and even before.

I was born in Oakland, CA and raised in Berkeley, CA. I represent the Bay Area to the fullest. That is what really makes me who I am. We have a loyalty to each other regardless of race because we moved past that in elementary school since our classes were so diverse that we got to know people of all races on a personal level at such an early age. That destroyed any potential stereotypes because we already knew people of many different ethnicities so you didn't group all people together who match some characteristic based on their physical appearance. We always took people for who they were and really followed Dr. King's dream of accepting each other. When you represent the Bay Area you represent a real community; it's a family. The birthplace of The Black Panther Party for Self Defense stands up as a collective for those who are true to it. We back each other up because we are real, and we are loyal.

Now that I have gotten that out of the way and given you a bit of background on myself, lets discuss the Black Lives Matter movement and the importance of creating a new movement.

\section{The History of the Black Lives Matter Movement}

"Confessions of a trigger happy hitman; murderous, homicidal nature, the racist plan 
Burying black boys, the bloodthirsty hunger games; the face of race is white, they have no shame

'Stand Your Ground' they legalize lynch laws; touch another black kid you touch us all"

—Public Enemy - Beyond Trayvon (Enemy 2012)

The social media hashtag \#blacklivesmatter was created in response to the acquittal of George Zimmerman in July 2013 for the murder of 17year-old Trayvon Martin in the court case State of Florida vs. George Zimmerman. This simple but powerful statement became a movement that has sparked a nationwide debate in the almost three years since its creation. The problem of modern racism is an important discussion to be had; racial tensions seem to be getting more heated as Black Communities nationwide are increasingly falling victim to many forms of oppression. The frustration mounts up, especially since officers of the law who are supposed to protect and to serve are the ones committing the worst acts against Black civilians; and more often than not, young Black citizens.

Now, obviously George Zimmerman was not an officer of the law. He was a neighborhood watch man who was even told not to pursue the "suspect" (young Trayvon). But the fact that a civilian could get away with a murder like this just showed how a young Black male can be targeted as a threat and then have his life disrespected and violated to the point where his actions and manner of dress can be used as a cause for his own murder.

Camille Gear Rich (2014) uses the critiques of Angela Harris to illustrate the ideas of perceived masculinity in her assessment of this trial that rocked our nation. She describes how our society follows a hierarchy of race and class which makes "minority men more vulnerable to both white and state-sponsored violence." In this case, Zimmerman (a man of Latino and white decent) chose to identify with a white position of power that "provided him with the maximum amount of social power and privilege during the conflict," and therefore perceived Martin as a suspicious character and pursued him.

Furthermore, why did it seem like the positive characteristics or accomplishments of this young man were never mentioned? Such as the fact that Trayvon went to Aviation School, with aspirations of becoming a pilot or working on planes (Burch and Isensee 2012).

Katheryn Russell-Brown (2009) discusses the phenomenon of how the media's overwhelming depiction of Black men as criminals perpetuates a stereotype where viewers "incorrectly conclude that most Black Men are criminals." She references this as the "myth of the criminalblackman." 
But let's ask the real question of how the whole thing started: How many white kids do you know are followed through their neighborhood (or more accurately stalked) because a neighborhood watch guy thought they were suspicious? These situations happen because people succumb to the power of stereotypes and then react in fear (hooks 1992).

Yet now, in the few years after the acquittal, we have seen the actions of George Zimmerman because of social media sharing the newest updates on the nationwide debate. He has had several more run-ins with the law which include multiple domestic violence charges (McDonough 2015). In retrospect it seems quite possible that maybe he is just a violent man who stalked and killed an innocent young teenager.

Now, let me be clear; the Trayvon Martin case is not the first incident in which a young Black individual has been killed, and the officer or citizen who committed the act (I do not say crime because almost all incidents did not even result in an indictment) went unpunished. Let's take a look at just a few from the past that illustrate the fact that the brutality has never stopped. There was no time when racism was "a thing of the past" as has been the myth in this country for the last twenty years or so.

\begin{tabular}{|l|l|l|l|}
\hline \multicolumn{1}{|c|}{ Name } & Year & Age & \multicolumn{1}{c|}{ Description } \\
\hline Sean Bell & 2006 & 23 & $\begin{array}{l}\text { Killed by police shooting 50 shots at him and } \\
\text { 3 other friends after a bachelor party. He was } \\
\text { getting married the next day. }\end{array}$ \\
\hline Oscar Grant & 2009 & 23 & $\begin{array}{l}\text { Killed by police on New Year's Day. Unarmed } \\
\text { and handcuffed when he was shot in the back, } \\
\text { face down on the ground. }\end{array}$ \\
\hline Amadou Diallo & 1999 & 22 & $\begin{array}{l}\text { Killed by police firing 41 shots, hitting him 19 } \\
\text { times right outside of his apartment. }\end{array}$ \\
\hline Fred Hampton & 1969 & 21 & $\begin{array}{l}\text { Murdered by the Chicago police department as } \\
\text { he was asleep in bed. A prominent Black } \\
\text { Panther leader they had to silence. }\end{array}$ \\
\hline Bobby Hutton & 1968 & 17 & $\begin{array}{l}\text { Shot by police over 12 times after surrendering } \\
\text { to police. He had stripped down to his } \\
\text { underwear to show he wasn't armed. }\end{array}$ \\
\hline
\end{tabular}

Many others have been victims of murders by police or average citizens where there was no punishment before this specific case. It's been going on for many years before our cell phones/smart phones had been so easily available to capture the images of such horrific actions by the police (although the Oscar Grant murder was actually caught on video which sparked outrage).

The birth of the Black Lives Matter movement was an outcry saying, 'Enough is enough! Our lives do matter!' 
Since the Trayvon Martin case there have been many more incidents. The table below illustrates just some of those incidents that gained the most media coverage.

\begin{tabular}{|l|l|l|l|}
\hline \multicolumn{1}{|c|}{ Victim } & Year & Age & \multicolumn{1}{c|}{ Description } \\
\hline Jordan Davis & 2012 & 17 & $\begin{array}{l}\text { Killed by a white male because his friends } \\
\text { were playing their "thug music" too loud - } \\
\text { significant because he was the next Trayvon } \\
\text { Martin. }\end{array}$ \\
\hline Michael Brown & 2014 & 18 & $\begin{array}{l}\text { Shot in the back and head with his hands up, } \\
\text { screaming "don't shoot." Left in the middle of } \\
\text { the street, dead, for hours - no indictment. }\end{array}$ \\
\hline Eric Garner & 2014 & 43 & $\begin{array}{l}\text { Calling out "I can't breathe" while being } \\
\text { choked to death by multiple officers - no } \\
\text { indictment, but the man who filmed it went to } \\
\text { prison. }\end{array}$ \\
\hline Tamir Rice & 12 & $\begin{array}{l}\text { Just 12 years old playing with a toy gun. } \\
\text { Officers shot him within seconds of exiting } \\
\text { their vehicle, guns raised. No indictment. }\end{array}$ \\
\hline Freddie Gray & 2015 & 25 & $\begin{array}{l}\text { Dead after sustaining injuries to his spinal cord } \\
\text { in police custody. Ruled a homicide with } \\
\text { multiple charges brought against officers. }\end{array}$ \\
\hline
\end{tabular}

Walter Lamar Scott, 50, is gunned down in South Carolina by Officer Michael T. Slager who would have gotten away with the murder if he hadn't been caught on video. Slager followed the usual cop script and claimed to be in fear of his life - that ever so familiar justification from any police officer who had killed an innocent civilian. The media was even framing it as such, taking the officer's word for it in the initial reports. And then a video surfaces; and we see how the officer felt a man running away from him was guilty enough to be killed, firing 8 continuous shots into his back. Walter Scott was shot down as if he were target practice in a sick, twisted game that the officer and his fellow boys in blue like to try to get away with. That's the only explanation for someone killing another human being like that. He did not respect human life.

The significance of this event is that Time Magazine took notice and did a feature story on it for their April 20th edition.

The iconic magazine had Black Lives Matter in huge white letters over a Black background on its cover and a picture of Walter Scott running for his life while a cop aimed his gun, ready to kill. This time, the officer Michael T. Slager, is charged with murder, and rightfully so (Drehle 2015).

You would think this incident and the consequences would actually make a difference in the attitudes of officers across the nation. Yet, we have seen more deaths at the hands of the police than any other nation in the world (Larter 2015). 
So let's take a look at other incidents that resulted in the death of a Black civilian at the hands of the police since the Walter Scott murder in April of 2015. And I'm writing this article in December of 2015. Think about that. Within eight months, the following events happened. But these are just the cases that have made headlines in which the police were involved.

\begin{tabular}{|l|l|l|l|}
\hline \multicolumn{1}{|c|}{ Name } & Year & Age & \multicolumn{1}{c|}{ Description } \\
\hline Sandra Bland & 2015 & 28 & $\begin{array}{l}\text { Arrested for traffic violation. Found dead in } \\
\text { her cell 3 days later. Labeled a suicide } \\
\text { initially. In 2016 those claims are being } \\
\text { refuted. }\end{array}$ \\
\hline Laquan McDonald & 2015 & 17 & $\begin{array}{l}\text { Shot 16 times by an officer seconds after } \\
\text { getting out of his squad car. He was walking } \\
\text { away, unarmed and no threat. }\end{array}$ \\
\hline Mario Woods & 2015 & 26 & $\begin{array}{l}\text { Executed by firing squad or shot by the SFPD. } \\
\text { However you want to frame it he was } \\
\text { murdered in broad daylight by the SFPD. }\end{array}$ \\
\hline Jamar Clark & 2015 & 24 & $\begin{array}{l}\text { Shot dead while in handcuffs in Minneapolis, } \\
\text { MN by officers who claim he wasn't cuffed } \\
\text { and reached for his gun. }\end{array}$ \\
\hline
\end{tabular}

Now, if you thought any of these killings at the hands of the police were justifiable I am not quite sure what to tell you. But I have saved a few incidents to really speak about the still horrific state that our country is in when it comes to equality between the races. So let's get a little less morbid. How about if we just talk about certain events that didn't lead to a death? In these incidents, thankfully nobody was killed but you never know when someone could actually go crazy and think they have the right to take another's life. Especially when it comes to law enforcement. In the first instance a cop even pulls a gun on two unarmed kids. So let's discuss.

\section{Ferguson Protests following the Michael Brown murder}

The Ferguson protests are reminiscent of year's past incidents of Black protesters and the police. The police show up to protests with nothing less than what can be described as military gear. They show up with tanks and handheld weapons that soldiers at war would carry, but these officers are just responding to demonstrators. The problem here is that the citizens who are just having their voices heard are met with such force, and what I could only described as fear. The State was so scared of anyone speaking up and criticizing the system so that those who were in charge of the response pulled out all the stops as if they were at war with citizens who were not even armed. Just look at the pictures. In one picture you have a solitary, innocent Black man with his hands up facing five or six officers in full "military" uniform who are pointing assault 
rifles at him. This is walking down a street in the United States of America.

How would you feel if you were approached by officers with guns raised aiming at you in your own neighborhood? And for gun enthusiasts who think that every citizen should be carrying a gun saying that a good man with a gun can stop a bad man with a gun. . . well, what do you think would have happened to this kid if he had a gun on him? 'Hands up, don't shoot' would have been followed by 'Watch out! He's got a gun!' - and maybe multiple gunshots killing him. You never know if you are not careful in today's society with police officers seeming to need just the slightest reason to put multiple bullets into a Black person.

Think about that and let it really sink in. The complexion of a human being's skin can determine life or death in our American Society. The land of the free and the home of the brave.

\section{BAltimore "RIOts" in Response to the Freddie Gray MURder}

"How can I feel guilty after all the things they did to me?

Sweated me, hunted me; trapped in my own community

One day I'm gonna bust, blow up on this society

Why did you lie to me? I couldn't find a trace of equality"

\section{-2Pac - Trapped (Shakur 1991)}

In the wake of the death of Freddie Gray in Baltimore young individuals of the community expressed their frustrations and anger toward the police; sometimes violently. Most of the responses to this young man's tragic death at the hands of the police were peaceful and organized protests. However, the focus of most of the media coverage was unfortunately the negativity, with terms like "thugs," "criminals," and even "wild animals" being used to describe all of the individuals involved.

The reporting on these events followed a usual theme the media follows anytime people of color are involved in any type of violent disruption that results in damage to businesses or confrontations with police officers. Their actions are presented in a negative light filled with condemnation. In contrast, anytime an incident breaks out in which the same type of destruction and confrontations occur but the individuals are predominantly white, the media never uses the same language condemning their actions. These are usually incidents in which "fans" are reacting in anger to one of their favorite sports teams losing a major game or series - so of course these white kids are just "blowing off steam" or "got a little out of hand" to the reporters covering such incidents. They are characterized as just being young and stupid - not thugs or criminals.

The unfortunate but inevitable result of this difference in reporting is a bias that the average viewer develops while viewing the coverage of 
each incident. People are only presented a piece of the story to fit a certain slant the media is presenting. As a deeper result, the machine that is Systemic Racism is solidified more and more in the minds of the American people without them even knowing it. Believing everything the media presents to them as if it were fact supplants the programming of their minds, affecting people's ability to think for themselves and question what they see - demanding more information and forming their own conclusions. We The People are told something by the media and we are supposed to believe it, no questions asked, and that story becomes fact.

\section{SAE FRATERNITY CAUGHT ON VIDEO SINGING RACIST CHANT ON BUS}

Meanwhile in Oklahoma, we have the lynching and the hanging of Black people being celebrated on a bus full of white fraternity brothers on March 7, 2015 (Kingkade 2015). A video was shared on Youtube.com by an anonymous poster showing the whole bus of passengers chanting with glee:

"There will never be a $\mathrm{n} * * * * *$ in SAE There will never be a $n * * * * *$ in SAE You can hang him from a tree, but he can never sign with me There will never be a ***** in SAE" (Kingkade 2015)

Of course they did not expect for someone to take a video of the situation and post it on the internet. Excuses arise for the actions of the individuals as if they were not usually racist, they were just drunk. Well that doesn't erase the chant, which must have been something they were taught. This goes back to an organizational racism. Think about it. . . without it being said this is an all white fraternity. This means that any student who was not white and rushed the frat would have been harassed, belittled, and degraded at every turn in order to keep the house "pure" and white.

\section{Berkeley High School Walks Out}

My old High School, Berkeley High, was in the news for standing up to racism in 2015. This reminded me of when I was a kid and my classmates and I walked out of our classes in protest of the Rodney King verdict, the (first) Iraq War, and Prop 187.

But in 2015 there were protests because of racism within the school that represented the comeback of white supremacy in our society today. A hateful message was found on library computers calling Blacks " $\mathrm{n} * * * * * \mathrm{~s}$ " and threatening violence. (Lee 2015). And yet there were a couple of other incidents that I had never heard of, including a noose that 
was found hanging from a tree on campus earlier in the year. That was reminiscent of the Jena 6 from 2006.

These are issues that are part of the Black Lives Matter Movement. And I can't believe these incidents happened at my old High School. Berkeley, the city in which I was born and raised and have been most influenced by is in the news for racism and threatening students with what can only be described as an horrific act that would have been carried out in the Jim Crow era of the South back in the 50s and 60s.

Yep, that's how far we've come ladies and gentlemen. Our society has become stagnant. Its morals have not advanced despite the advances that unity has created in our history.

\section{White Supremacist Groups Infiltrating Modern Police Forces}

"You need a little clarity, check the similarity:

The overseer rode around the plantation - The officer is off, patrolling all the nation. . .

The overseer had the right to get ill, and if you fought back the overseer had the right to kill

The officer has the right to arrest, and if you fight back they put a hole in your chest"

\section{—KRS-ONE - Sound of da Police (1993)}

It's no secret that police departments throughout the nation have historically employed racist individuals who abused their powers in brutalizing African Americans. From the time of Slavery, to Reconstruction, and then Jim Crow this was the norm. As race relations progressed, society began to move away from this norm and push for the rights of all citizens (Gray 1995).

However, individuals like Alabama Governor George Wallace, Jim Clark, a sheriff of Dallas County, Alabama (1955-1966) and Eugene "Bull" Connor, Commissioner of Public Safety for Birmingham, Alabama (1937-1952, and again from 1957-1963), opposed desegregation so drastically and violently during the Civil Rights Movement era that the federal government had to intervene in order to have the new laws enforced. Police Departments like this made headlines for their outspoken racism and even employed individuals who were members of the $\mathrm{Ku}$ Klux Klan, often participating in the lynching of African American citizens in the Jim Crow south.

Over the years the Civil Rights and Black Power movements led to the government passing new laws such as the Civil Rights Acts of 1957, 1960, 1964, 1968 (Fair Housing Act), and 1991, and the Voting Rights Acts of 1965, 1970, 1975, and 1982 which outlawed discrimination in many forms to all citizens regardless of any differences (U.S. Govern- 
ment Printing Office 2008). Naturally, as a result Police Departments across the nation became less racist and upheld the rights of all citizens.

However, some departments progressed much slower than others depending on the history of each specific area of the country and the lack of change in attitudes of the local individuals living there. The predominant views of citizens within these communities did not change simply because a few laws were passed.

Fast forward to the 2000s and smart phones and social media allow us all to see more and more issues between the police and people of color. These incidents of police abusing their power are nothing new, but now modern technology is allowing anyone with the right phone to record and expose the lies used to cover up horrific acts. This exposure leads us to the current state of tensions we have and some would wonder why it feels like law enforcement is regressing in their relations with citizens. Racism seems to be a huge part of the explanation when addressing what leads to each incident. One of the most important pieces of evidence to support this theory was a warning by the Federal Bureau of Investigations (FBI) from 2006 which described "white supremacists' infiltration of law enforcement" as a significant national threat (FBI Counter Terrorism Division 2006). More and more instances support this warning. Samuel V. Jones points out multiple situations in evidence of the truth of these claims by the FBI (Jones 2015). Within my own native Bay Area, the city of San Francisco currently employs several officers who just recently were acquitted on a technicality after sending racist text messages back and forth (V. Lee 2015). And these are officers who are sworn to protect anyone and everyone in their city. Yet they have a white supremacist bias within their hearts. Unacceptable.

\section{The University of Missouri Protests}

In the state of Missouri, the Michael Brown murder and subsequent decision not to indict the officer who killed him reverberated across the whole surrounding region. University of Missouri students made it clear that the injustices they were experiencing on their campus should not be ignored. Once they chose to press on they shed light on the racial prejudices inherent in the state. Major incidents such as the actions of the University of Missouri stir up major emotions in all people. This ignites a specific fire within people that says: enough is enough. A difference has to be made, right here and now.

It started small. The Student Government President - a young Black man - was walking across campus as a group of people in the back of a pickup truck started hurling racial slurs at him. He had the courage and anger/adrenaline to express his feelings on social media by stating, "For those of you who wonder why I'm always talking about the importance 
of inclusion and respect, it's because I've experienced moments like this multiple times at THIS university, making me not feel included here" (Pearson 2015). His protest became a widely shared post.

A "Racism Lives Here" rally is held on campus with around forty students sharing stories of racism to which they have been subjected while chanting "white silence is violence, no justice no peace." (Nashkidashvili 2015)

What emerged next was an emotional protest in which a group of students stood up to the university president riding in his car during a Homecoming rally. Unfortunately, the president ignored them; but these young, determined individuals continued on. They stood together, organized in protest to the president's actions. United with their arms locked, these courageous soldiers of the modern struggle stated historical facts about the repeated racist actions of the institution they chose to attend to receive their higher education. In a typical reaction of the dominant community, the young protestors were met by individuals trying to silence them, but they were able to finish their intended message. The young brothers and sisters stated their grievances and were heard; even if just by those who needed to see and hear it (Kingkade 2015).

Following the protest, students called for the resignation of the university president, Tim Wolfe, among other demands they presented in protest. One student went on a hunger strike and the football team refused to practice or play any game until the school president stepped down. That is huge.

You have a Division 1 football team refusing to play until the president steps down in a show of solidarity with their Black brothers and sisters of the university. This was their school. They showed they will stand up to racism and won't back down no matter how much money the university stands to lose. They stood united. Their continued pressure was heard and they took a huge step towards the validation of the struggle for Human Rights (ESPN.com News Services 2015).

Once the president of the university stepped down the young racists of the school began to come out of the shadows. They posted on social media spewing threats and using racist slurs, showing the true feelings residing and growing within their hearts. Some went as far as to claim "I'm going to stand my ground and shoot any black person I see" and "Some of you are alright. Don't go to campus tomorrow" (Yan and Stapleton 2015). These are threats of mass killings. Another shooting on a college campus. Why didn't the press make a big deal out of this? The answer to that is pretty obvious in our systemically racist society. Tensions still continue at the University of Missouri as well as other campuses across the nation that followed the lead with protests of their own. 


\section{June 17, 2015 - Charleston, SC Church Massacre}

A young white supremacist walks into the Emanuel African Methodist Episcopal Church and after talking with them for about an hour decides to open fire on this peaceful gathering because he wanted to kill Blacks. He targeted this church because it was a historically Black institution. Nine people are murdered. All just regular everyday people you would encounter anywhere. All with families and loved ones. All respected by the community.

The killer's manifesto discusses how he feels that Blacks are inferior to whites and he wanted to plan a perfect target to carry out retaliation for what he thought was Black on white crime. "I chose Charleston because it is most historic city in my state, and at one time had the highest ratio of blacks to Whites in the country. We have no skinheads, no real KKK, no one doing anything but taking on the internet. Well someone has to have the bravery to take it to the real world, and I guess it has to be me" (McLaughlin 2015).

He referenced the Trayvon Martin case as a turning point for him, claiming that George Zimmerman was "obviously in the right," and that it motivated him to research Black on white crime on the Internet. Within this diatribe he addressed different races specifically as if he was writing a research paper using multiple racial slurs. The only way to describe his writing is hate-filled speech with misguided views based on the teachings of white supremacist ideals. He felt the need to seek out the racist rhetoric to feel stronger and find others who agreed with him.

In the aftermath of the massacre the police went on a manhunt for the suspect and when they caught him, an incredible thing happened. . . they actually put away their guns and walked up to the car opening the door and letting the young white man out, arresting him peacefully. The cops were (almost) all white and obviously took it easy on this kid. I am reminded of the Dave Chappelle standup comedy act in which he talked about his white friend Chip who has very different encounters with police than a Black man does (Chappelle 2000).

Think about the hypocrisy of this arrest. If it were a young Black male who killed nine white people at church I doubt he would have been able to even get out of his car without being shot multiple times, with the officers claiming they were fearing for their lives and saying there was a gun pulled on them. He was obviously armed and extremely dangerous when he was pulled over so how was this such an easy arrest?

That is white privilege plain and simple.

However, it does not stop there. While the officers were driving him to jail this mass murderer claimed he was hungry. So they take him to Burger King and buy him a meal. I was in shock when I read about that. As police officers arresting a stone cold killer you don't take him to any 
restaurant, feeling sorry for him. You take him straight to jail, do not pass go, do not collect Burger King! (a Monopoly board game reference for all who don't know)

All of this situation; the reaction of the mass media and the police is just more evidence to throw onto the fire in trying to explain Systemic Racism to anyone who really does not understand it, because it is not very clear cut. It is hidden from the public.

Note: *I'm keeping Blacks in uppercase and whites in lowercase for a reason in this portion of my paper. Dylann Roof's manifesto always had "blacks" and "Whites" - shows how he really did feel Black people are inferior.

\section{THE RESPONSE OF “ALL LIVES MATTER” AND WHY IT'S MisLEADING}

If you have gotten this far in reading my thoughts, I hope you have absorbed what I have been discussing throughout this piece. If you have not and skipped ahead to just read my response to "all lives matter" then you do not have the proper state of mind in order to understand what I am about to say. So, if that is the case, then I respectfully ask you not to proceed any further in reading this piece, and start right back up at the top where it says Black Lives Matter.

Now, there is a common response of those uneducated to the point of the ideal of the Black Lives Matter movement in which they seem to feel the need to claim that "all lives matter." No shit. We all know that; or at least we are supposed to know this fact. Anyone who has a heart or values life in any way in our society knows that all lives matter. However, in this complex society of ours where we are judged by all of our itemized differences you have to acknowledge the fact that Black lives have been forgotten in that counter-statement. If Black lives had been included in the "all lives matter" counter statement the issue of police murders and brutality would not be debated. It would be an outcry from every citizen, in every city and every state across the nation in response to any and every unjust killing at the hands of anyone, not just when it is a Black life taken by police; but when it is a human being's life taken unjustly by another human being, regardless of the position they hold in society. But we do not see that.

That is from where the need to proclaim that Black Lives Matter stems. It is a statement reminding those who have forgotten that Black lives are indeed supposed to be included as equals in this nation. The fact that there has to be a reminder is a wakeup call to everyone showing that we are not living in a Post-Racial Society. Those who state "all lives matter" in response are almost brushing off the proclamation of the pop- 
ulation being unjustly targeted by law enforcement and racist individuals as if to say, "yeah, yeah, shut up, we don't want to hear it."

And the biggest question to be asked is, well, why don't you want to hear it? Are you so caught up in your own life that you feel anyone you don't agree with deserves such treatment from those who are sworn to protect us? And I mean all of us as American citizens. Is there really justification for an officer who gets out of a car and shoots to kill a 12year old child who is playing with a toy gun? Do you actually believe that an unarmed man walking away from a police officer deserves to be shot multiple times until dead?

I understand police have a tough job, but if you are an officer of the law I would hope you've gone through some combat training and can defend yourself, rather than fearing for your life because you felt you were being overpowered by a 12,17 , or 18 -year old kid. If it was that easy to take your weapon then you were not fit to be an officer in the first place. But that is a whole other debate to be had at another time.

Black Lives Matter is much more of a statement in today's society than any organization. You do not have to represent an organization to say to yourself that there is a true bias in our society based on the color of a person's skin. I stand by this statement that means so much in our society right now because it has sparked a movement that I have been waiting to see for years now. I guess I needed an organization and statement to rally behind, and now I can voice my support.

My thoughts as a critic on how to edit the statement of "all lives matter" would have to be saying that "all lives should matter". . . but they really don't in our society. When Black Lives Matter, Hispanic/ Latino Lives Matter, Asian Lives Matter, Muslim Lives Matter, LGBT Lives Matter, etc. then we can actually say "all lives matter".

We need to move forward as a full society that is all inclusive of even the most subtle differences. We should have been over this whole difference in skin tone thing a long time ago. For that matter we should have been over the whole differences in religion a long time ago as well which is why this country has freedom of religion.

\section{Hate Group?}

“They're a hate group. And I'll tell you right now, I'm going to put them out of business."

-Bill O'Reilly discussing Black Lives Matter on his show The O’Reilly Factor, August 21, 2015.

I would like to state right here and now that if the Black Lives Matter organization is a "hate group" then I am a "thug." Yes, a 38-year old white male who has nothing more than a speeding ticket on his re- 
cord and has been a good citizen, is a "thug." That's how outrageous that claim trying to demean the Black Lives Matter movement is to me.

Once the movement started gaining some momentum certain people who didn't understand the need for a modern movement to keep the fight for equality alive started blaming Black Lives Matter for some tragic events in which police were killed. One example of this reaction was when a sheriff in Houston, TX mentioned the Black Lives Matter movement when discussing the killing of a fellow sheriff on August 28, 2015. "We've heard Black Lives Matter, All Lives Matter. Well, cops' lives matter, too." (CBS/AP 2015). It was tragic for someone to get killed, of course, but police sign up for that danger and to blame this horrible act on a peaceful movement is unfair and perpetuates a false, negative perception of the group. Their aim is to reduce violence, not encourage it.

It is disappointing that in our current society, one in which I thought we were progressing forward, some people actually think that the Black Lives Matter movement is a hate group that wants to "kill whites." I do not know about you, dear reader, but that sounds like real paranoia.

\section{Conclusion}

Some people fear what they do not understand and react negatively. I seek to understand what I do not know in order to create positivity and reduce the fear in others. Fear is truly the biggest hindrance of what would be the ultimate goal of unity among all human beings. Fear keeps everyone from continuing what our past leaders accomplished. Our nation has not learned from the mistakes of those who came before us and it shows in the ignorance of our overall population when it comes to racial matters. The evil of the elite who psychologically want to keep us divided is winning because people are so afraid to get out of their comfort zone and question what they have been taught. It is time to change that situation and education is desperately needed in our society to move forward. The Black Lives Matter movement is just the beginning of a positive change.

\section{Works Cited}

Blumberg, Rhoda Luis. Civil Rights: The 1960s Freedom Struggle, Revised Edition. New York, NY: Twayne Publishers, 1991.

Burch, Audra D.S., and Laura Isensee. "Trayvon Martin, a typical teen with dreams of flying or fixing planes." Tampa Bay Times. March 22, 2012 http://www.tampabay.com/news/publicsafety/crime/tray von-martin-a-typical-teen-with-dreams-of-flying-or-fixing-planes/ 1221425 (accessed March 2, 2016). 
CBS/AP. "Sheriff links "Black Lives Matter" movement to slain deputy." CBS News. August 31, 2015. http://www.cbsnews.com/news/ darren-goforth-killing-sheriff-cites-black-lives-matter-movement/ (accessed January 2016).

Drehle, David Von. "Line of Fire.” Time Magazine, 2015: 24-29.

Enemy, Public. "Beyond Trayvon." The Evil Empire of Everything. 2012.

ESPN.com News Services. "Missouri Tigers football players to strike until embattled Tim Wolfe resigns." ESPN.com. November 8, 2015. http://espn.go.com/collegefootball/story/_/id/14078494/missouritigers-football-players-strike-embattled-tim-wolfe-resigns (accessed March 6, 2016).

FBI Counter Terrorism Division. "White Supremacist Infiltration of Law Enforcement." Federal Bureau of Investigation Intelligence Assessment. October 17, 2006. http://s3.documentcloud.org/documents/ 402521/doc-26-white-supremacist-infiltration.pdf (accessed January 2016).

Figueroa, Julie Lopez. "Framing the Value and Purpose of Perspectives." In Introduction to Ethnic Studies, by Julie Lopez Figueroa, Boatamo Mosupyoe and Brian Baker, 5-10. Dubuque, IA: Kent/Hunt Publishing Company, 2007.

Gear Rich, Camille. "Angela Harris and the Racial Politics of Masculinity: Trayvon Martin, George Zimmerman, and the Dilemmas of Desiring Whiteness." California Law Review 102 Cal. L. Rev. 1027 (August 2014): 1027-1052.

Gray, Fred. Bus Ride To Justice: Changing the System by the System. The Life and Works of Fred Gray. Montgomery, AL: Black Belt Press, 1995.

Griffin, John Howard. Black Like Me . New York : Penguin Group, 2010.

Hine, Darlene Clark, William C. Hine, and Stanley Harrold. African Americans: A Concise History - Volume One: To 1877. Upper Saddle River, NJ: Prentice Hall, 2004.

hooks, bell. Black Looks: race and representation. Cambridge, MA: South End Press, 1992.

Jones, Samuel V. "FBI's warning of white supremacists infiltrating law enforcement nearly forgotten." The Grio. May 12, 2015. http:// thegrio.com/2015/05/12/fbi-white-supremacists-law-enforcement/ (accessed January 2016). 
Kingkade, Tyler. "Oklahoma Frat Boys Caught Singing 'There Will Never Be A N***** In SAE'." Huffington Post. March 9, 2015. http://www.huffingtonpost.com/2015/03/08/frat-racist-sae-oklaho ma_n_6828212.html (accessed January 2016).

. "The Incident You Have To See To Understand Why Students Wanted Mizzou's President To Go." The Huffington Post. November 11, 2015. http://www.huffingtonpost.com/entry/tim-wolfe-home coming-parade_us_56402cc8e4b0307f2cadea10 (accessed January 2016).

KRS-ONE. "Sound of da Police." Return of the Boom Bap. 1993.

Larter, Jamiles. "By the numbers: US police kill more in days than other countries do in years." $w w w$.theguardian.com. June 09, 2015. http:// www.theguardian.com/us-news/2015/jun/09/the-counted-policekillings-us-vs-other-countries (accessed January 2016).

Lee, Seung. "Berkeley High School Students Walk Out In Protest Against Discovered Racial Epithet." Newsweek. November 5, 2015. http://www.newsweek.com/berkeley-high-school-students-walkout-protest-against-discovered-racial-391262 (accessed January 2016).

Lee, Vic. "SF Judge: 7 SFPD Officers Can't Be Punished for Racist Text Messages." ABC7News.com. December 21, 2015. http://abc7news .com/news/sf-judge-7-sfpd-officers-cant-be-punished-for-racisttext-messages/1131589/ (accessed March 6, 2016).

McDonough, Katie. "George Zimmerman arrested for domestic violence again - Will he finally lose his guns? - Salon.com." Salon.com. January 12, 2015. http://www.salon.com/2015/01/12/george_zimmer man_arrested_for_domestic_violence_again/ (accessed January 2016).

McLaughlin, Michael. "Racist Manifesto Purportedly Written By Dylann Roof Surfaces Online." The Huffington Post. June 20, 2015. http:// www.huffingtonpost.com/2015/06/20/dylann-roof-manifesto-char leston-shooting_n_7627788.html (accessed January 2016).

Nashkidashvili, Nana. "Students march through MU Student Center in protest of racial injustice." http://www.columbiamissourian.com. October 1, 2015. http://www.columbiamissourian.com/news/higher _education/students-march-through-mu-student-center-in-protestof-racial/article_4b8e3458-688b-11e5-8412-9b38a4d41eb8.html (accessed January 2016).

National Urban League. The State of Black America 2007: Portrait of the Black Male. Silver Spring, MD: Beckham Publications Group, 2007. 
Omi, Michael, and Howard Winant. Racial Formation in the United States. Abingdon, Oxon: Rouledge, 1994.

Pearson, Michael. "A timeline of the University of Missouri protests." CNN. November 10, 2015. http://www.cnn.com/2015/11/09/us/mis souri-protest-timeline/ (accessed January 2016).

Roots, The. Don't Feel Right. 2006.

Russell-Brown, Katheryn. The Color of Crime. New York: New York University Press, 2009.

Shakur, Tupac. "Trapped." 2Pacalypse Now. 1991.

U.S. Government Printing Office. "Constitutional Amendments and Major Civil Rights Acts of Congress Referenced in Black Americans in Congress." History, Art \& Archives, U.S. House of Representatives, Office of the Historian, Black Americans in Congress, 1870-2007. 2008. http://history.house.gov/Exhibitions-and-Publications/BAIC/ Historical-Data/Constitutional-Amendments-and-Legislation/ (accessed February 26, 2016).

Yan, Holly, and AnnClaire Stapleton. "University of Missouri students report threats; police quell KKK rumors." CNN. November 11, 2015. http://www.cnn.com/2015/11/11/us/university-of-missouri-ra cism-protest/ (accessed March 6, 2016). 